\section{Methods and results}

Packaging paper for slides was stained with lactophenol cotton blue. This showed the presence of hyaline and septate hyphae. The slides and their wrappings were cultured on both Sabouraud dextrose-agar (S) medium containing chloramphenicol, and on S medium only. A heavy growth of suspected aspergillus colonies was obtained (figs 2 and 3 ). These colonies were investigated further by culturing them on both Czapek's solution agar and malt extract agar. Macroscopic and microscopic examination of their vegetative and reproductive sexual and asexual structures, and measurement of blastoconidia and ascospores, identified the fungus as Aspergillus chevalier from the Aspergillus glaucus group.

\section{Conclusions}

The contamination we found could be due to extended journey times and to docking of cargoships in warm and equatorial tropical areas. It is thus important when doing microscopy for fungal infections to obtain slides which are of adequate quality and sterility, as otherwise false positive results will be reported.

1 Raper KB, Fennel DI. The genus Aspergillus. Baltimore: Williams and Wilkins, 1965.

2 Upsher FJ. Microfungi at the Joint Tropical Research Unit, Innisfail, Queensland. In: Walters AH, Hueck-van der Plas $\mathrm{EH}$, eds. Biodeterioration of materials, vol 2. London: Applied Science Publishers, 1972:27-34.

\title{
Clear cell mammary malignant myoepithelioma with abundant glycogens
}

\author{
Hiroko Kuwabara, Hirotsugu Uda
}

Second Department of Pathology, Kagawa Medical University, Miki-Cho, Kita-Gun, Kagawa, 761-07, Japan

Correspondence to: Dr Kuwabara.

Accepted for publication 13 May 1997

\begin{abstract}
Malignant myoepithelioma (myoepithelial carcinoma) of the breast is extremely rare. A case is reported of a 46 year old female with clear cell mammary malignant myoepithelioma that, on histological examination, was glycogen abundant clear cell carcinoma. Immunohistochemically, the clear cells showed myoepithelial differentiation-that is, they were $\alpha$ smooth muscle actin and $\mathrm{S} 100$ protein positive. This case shows that glycogen abundant clear cell carcinoma is a variant of malignant myoepithelioma of the breast.

(F Clin Pathol 1997;50:700-702)
\end{abstract}

Keywords: clear cell; glycogen; malignant myoepithelioma

Myoepithelial cells have characteristics of both epithelial and smooth muscle cells. They are mainly present in the salivary glands and mammary glands. Myoepithelial neoplasms of the breast are extremely uncommon and they are classified into benign myoepitheliosis, malignant myoepithelioma (myoepithelial carcinoma), and adenomyoepithelioma showing biphasic epithelial and myoepithelial growth. Malignant myoepithelioma cells of the breast consist of spindle or polygonal cells, which sometimes mimic leiomyosarcoma. ${ }^{2}$ The cytoplasm of these tumour cells is eosinophilic or clear. Clear cell mammary malignant myoepithelioma, which did not show significant amounts of glycogen, was first reported by Cartagena et al in $1988 .^{3}$ We report a similar tumour that had abundant glycogens and
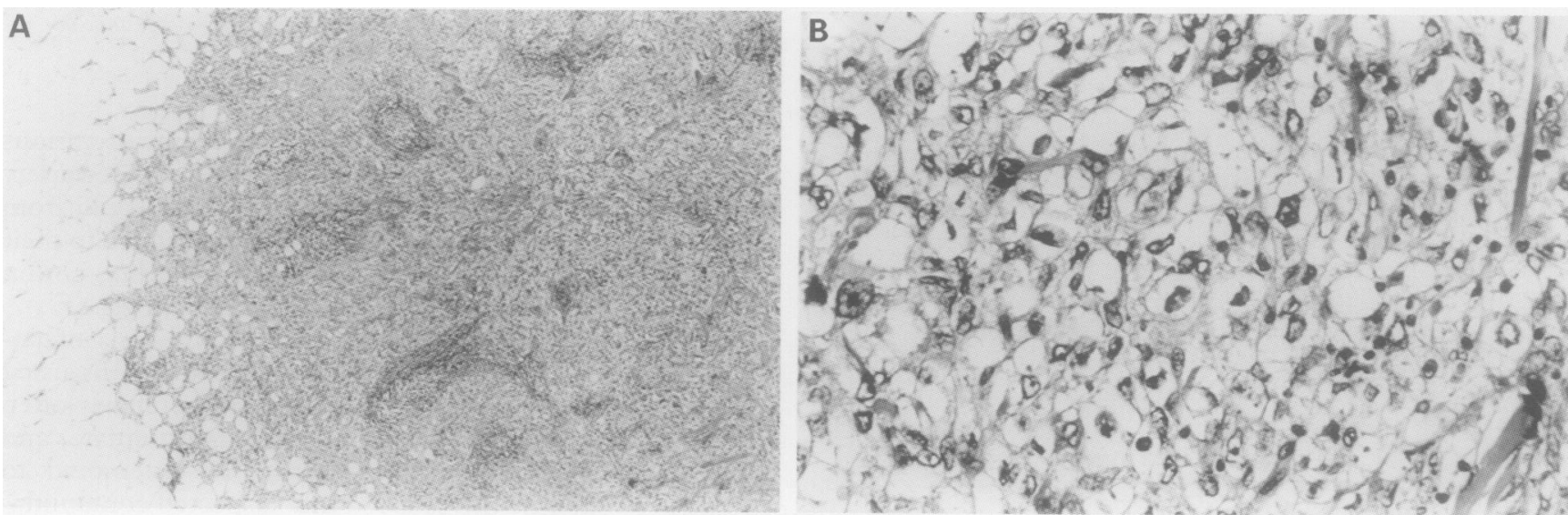

Figure 1 (A) Tumour showing infiltrative growth. (B) High power of view of (A). Tumour comprised pleomorphic polygonal cells with a clear cytoplasm. 
describe its histological and immunohistochemical findings.

\section{Case report}

A 46 year old female visited our hospital for investigation of a lump of the right breast. Fine needle aspiration cytology showed a few atypi-

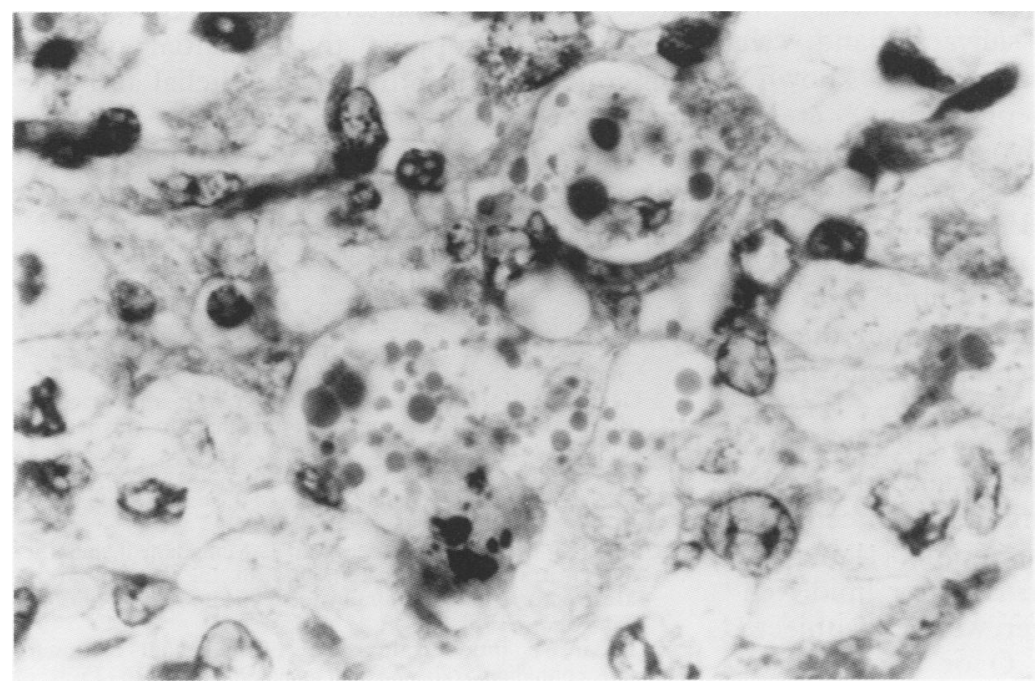

Figure 2 Clear cells with diastase PAS positive hyaline droplets.

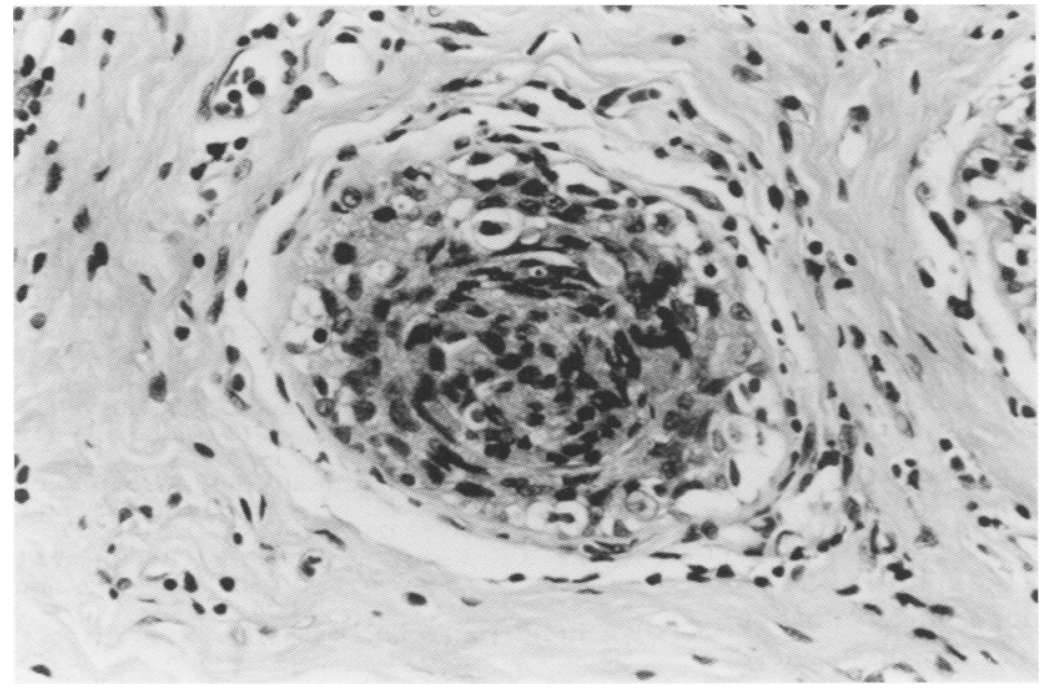

Figure 3 Intraductal carcinoma element adjoining the main tumour.

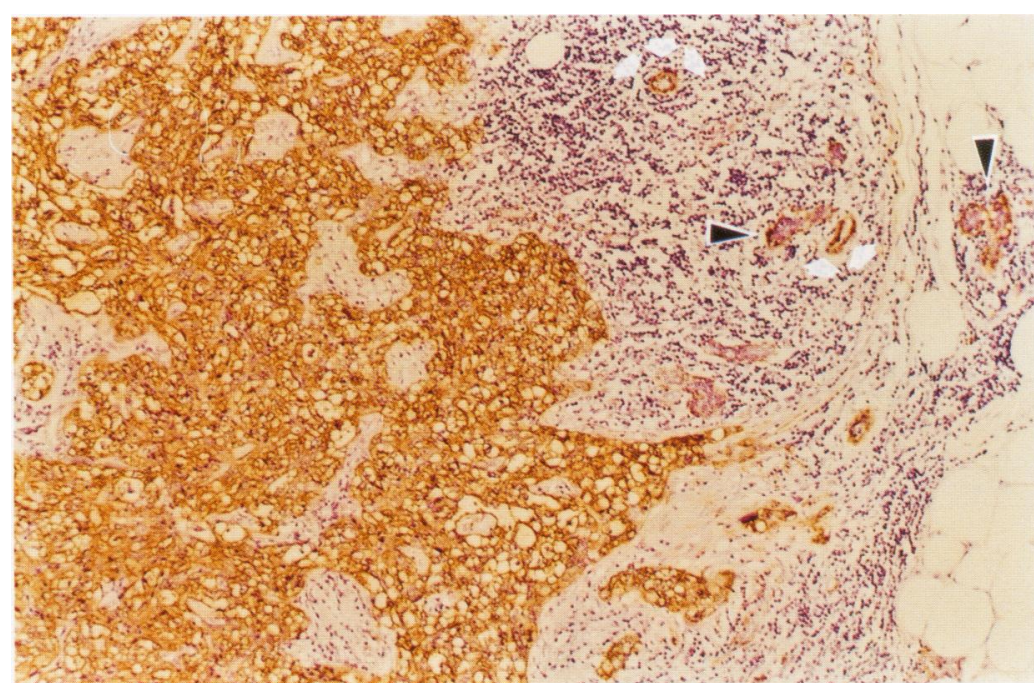

Figure 4 Almost all clear tumour cells were positive for aSMA antibody. Blood vessel walls (white arrows) and normal myoepithelial cells surrounding acini (arrowheads) are also positive for aSMA. cal cells that had a high suspicion of malignancy. The frozen section diagnosis of the incision biopsy was invasive carcinoma, and partial mastectomy with axillary lymph node dissection was performed. The mastectomy specimen contained a $2.3 \times 1.0 \mathrm{~cm}$ tumour. Oestrogen and progesterone receptor assays were negative. The surgical specimen was fixed in $10 \%$ buffered formalin and embedded in paraffin. The patient was free from local recurrence or metastases seven months after the surgery.

PATHOLOGICAL FINDINGS

A definite capsule was not found and the tumour had an infiltrative border (fig 1A). The neoplasm comprised mainly pleomorphic polygonal cells with clear cytoplasm (fig 1B). In the periodic acid-Schiff (PAS) reaction, the tumour cells showed abundant fine positive granules in the cytoplasm; most of these were digested with diastase. Mucicarmine staining was completely negative and oil red $\mathrm{O}$ staining confirmed the absence of intracytoplasmic lipid.

The nuclei were irregular with prominent nucleoli. There were $4-6$ mitoses per 10 high power fields. Irregular mitoses were also present. Some clear cells had diastase PAS positive hyaline droplets ranging in diameter from less than $2 \mu \mathrm{m}$ to approximately $15 \mu \mathrm{m}$ (fig 2). The stroma was composed of strands of hyalinised desmoplastic connective tissue. Occasional acidophilic spindle cells were present. Adjoining the main tumour, intraductal carcinoma consisting of peripheral clear cells and central spindle non-clear cells was present (fig 3). Around the tumour, severe lymphocytic infiltration was seen but there was no evidence of metastases to the axillary lymph nodes. Glandular formation by the tumour cells was completely absent.

\section{IMMUNOHISTOCHEMICAL FINDINGS}

The streptavidin-biotin peroxidase complex technique was performed using the following antibodies: $\alpha$ smooth muscle actin ( $\alpha \mathrm{SMA}$ ), S100 protein, epithelial membrane antigen (EMA), keratin, vimentin, desmin, glial fibrillary acidic protein (GFAP) (all Dako, Glostrup, Denmark), and gross cyst disease fluid protein (GCDFP15) (Signet Laboratories Inc, Dedhaw, Massachusetts, USA). Most of the clear tumour cells were positive for $\alpha$ SMA (fig 4); the staining pattern was diffuse, but was more intense in the cytoplasmic periphery. Most of the tumour cells in the cytoplasm were positive for $\mathrm{S} 100$ protein. Keratin and EMA were positive in some tumour cells. The other antibodies were negative. Hyaline droplets were negative for all antibodies tested, and the clear cells containing them were occasionally positive for EMA. However, peripheral clear cells of the intraductal carcinoma were positive for $\alpha$ SMA, S100 protein, and keratin. Central non-clear spindle cells were positive for keratin and $S 100$ protein, and negative for the other antibodies including $\alpha$ SMA. 


\section{Discussion}

Most of the tumour cells had clear cytoplasm and abundant glycogens. Immunohistochemical study showed that most of the clear cells were positive for $\alpha$ SMA and S100 protein, and some were keratin positive. These immunohistochemical findings suggested myoepithelial differentiation $^{145}$ (electron microscopy was not performed). In the salivary gland, clear cell-type with or without glycogens is known to be one variant of myoepithelioma, ${ }^{6}$ and in breast tissue clear cell myoepithelial elements of myoepitheliosis and adenomyoepithelioma have been reported. ${ }^{17}$ In 1988, Cartagena $e t ~ a l^{3}$ first reported clear cell mammary malignant myoepithelioma. However, tumour cells from the present case had infiltrated the surrounding fatty tissue and showed cellular pleomorphism and high mitotic activity. From these findings, we made a diagnosis of malignant myoepithelioma with a glycogen abundant clear cytoplasm. In other breast tumours, clear cells have appeared as secretory carcinoma, ${ }^{8}$ signet ring cell carcinoma, ${ }^{9}$ glycogen rich $^{10}$ or lipid rich ${ }^{11}$ carcinoma. These, however, were not subjected to mucicarmine, oil red $\mathrm{O}$ or immunohistochemical staining. Adenomyoepithelioma has been cited as the origin of malignant myoepithelioma, ${ }^{12}$ whereas in our case, intraductal carcinoma adjacent to the main tumour consisted of peripheral clear and central non-clear spindle cells. This resembles the intraductal growth of malignant myoepithelioma reported by Tamai. ${ }^{5}$

Until now, three glycogen rich clear cell malignant myoepithelioma cases have been reported, and they mainly showed intraductal or intralobular growth. ${ }^{513}$ The unusual finding of our case was diastase PAS positive hyaline droplets in the clear cell-type tumour cells. In clear cell myoepithelial neoplasm of the breast, Cartagena et $a l^{3}$ reported an occasional diastase PAS positive eosinophilic cytoplasm granule. In another study, the epithelial cells of the lobules and the terminal duct epithelium contained fine granules that were diastase PAS positive. ${ }^{14}$ The hyaline droplets of our case may have derived from the accumulation of fine diastase PAS positive granules in the ductal or lobular epithelium. In fact, the clear cells with hyaline droplets, which were immunohistochemically positive for EMA as well as $\alpha \mathrm{SMA}$ and S100 protein, had both epithelial and myoepithelial characteristics. Moreover, some investigators support the potential of dual differentiation into the myoepithelial and ductal epithelial cells of some mammary cells. ${ }^{15}$

This case shows that glycogen abundant clear cell carcinoma of the breast is a variant of malignant myoepithelioma.

1 Tavassoli FA. Myoepithelial lesions of the breast. Myoepitheliosis, adenomyoepithelioma, and myoepithelial carcinoma. Am f Surg Pathol 1991;15:554-68.

2 Cameron HM, Hamperl H, Warambo W. Leiomyosarcoma of the breast originating from myothelium (myoepithelium). F Pathol 1974;114:89-92.

3 Cartagena N Jr, Cabello-Inchausti B, Willis I, Poppiti R Jr. Clear cell myoepithelial neoplasm of the breast. Hum Patho 1988;19:1239-43.

4 Schurch W, Potvin C, Seemayer T. Malignant myoepithelioma (myoepithelial carcinoma) of the breast: an ultrastructural and immunohistochemical study. Ultrastructural Pathol 1985;8:1-11.

5 Tamai $M$. Intraductal growth of malignant mammary myoepithelioma. Am f Surg Pathol 1992;16:1116-25.

6 Saksela E, Tarkkanen J, Wartiovaara J. Parotid clear-cell adenoma of possible myoepithelial origin. Cancer 1972;30: $742-8$.

7 Eusebi V, Casadei GP, Bussolati G, Azzopardi JG. Adenomyoepithelioma of the breast with a distinctive type of apocrine adenosis. Histopathology 1987;11:305-15.

8 Oberman HA. Secretory carcinoma of the breast in adults. Am $\mathcal{f}$ Surg Pathol 1980;4:465-70.

9 Merino MJ, Livolsi VA. Signet ring cell carcinoma of the female breast: a clinicopathologic analysis of 14 cases. Cancer 1981;48:1830-7.

10 Hull MT, Warfel KA. Glycogen-rich clear cell carcinoma of the breast. A clinicopathologic and ultrastructural pathology. Am ₹ Surg Pathol 1986;10:553-9.

11 Romos CV, Taylor HB. Lipid-rich carcinoma of the breast. A clinicopathologic analysis of 13 examples. Cancer 1974;33:812-19.

12 Chen PC, Chen CK, Nicastri AD, Wait RB. Myoepithelial carcinoma of the breast with distant metastasis and accompanied by adenomyoepitheliomas. Histopathology 1994;24: p43-8.

13 Soares J, Tomasic G, Bucciarelli E, Eusebi V. Intralobular growth of myoepithelial cell carcinoma of the breast. Virchows Archiv 1994;425:205-10.

14 Barwick KW, Kashgarian M, Rosen PP. "Clear-cell" changes within duct and lobular epithelium of the human breast. Pathol Annu 1982;17:319-28.

15 Bennett DC, Peachey LA, Durbin H, Rudland PS. A possible mammary stem cell line. Cell 1978;15:283-98. 